\title{
EFFECTS OF DIFFERENT MIXED PLANTING PATTERNS OF CHINESE FIR (CUNNINGHAMIA LANCEOLATA) ON CHEMICAL FORMS OF ALUMINUM IN SOIL
}

\author{
ZHANG, J. ${ }^{*}-$ LIU, B. ${ }^{2}-$ CUI, P. ${ }^{1}-$ LIN, S..$^{*}$ \\ ${ }^{I}$ College of Life Science, Fujian Agriculture and Forestry University, Fuzhou 350002, China \\ ${ }^{2}$ College of Forestry, Fujian Agriculture and Forestry University, Fuzhou 350002, China \\ *Corresponding authors \\ e-mail: jbzhangfj@163.com; szlin53@126.com
}

(Received $8^{\text {th }}$ Aug 2018; accepted $2^{\text {nd }}$ Jan 2019)

\begin{abstract}
Aluminum (Al) toxicity is an important cause of forest degradation. Al phytotoxicity is closely related to its chemical forms in soils. In this study, the effects of different mixed planting patterns of Chinese fir (Cunninghamia lanceolata) on four chemical forms of $\mathrm{Al}$ in soils were examined. One-yearold seedlings of $C$. lanceolata, Michelia macclurei and Schima superba were used. The results showed that the content of exchangeable $\mathrm{Al}$ and monomer hydroxy $\mathrm{Al}$ decreased by $2.3-8.1 \%$ and $2.6-14.2 \%$ in soil of mixed plantation of C. lanceolata with $M$. macclurei, whereas they decreased by $6.6-6.9 \%$ and $7.2-7.3 \%$ in bulk soil of $C$. lanceolata mixed with $S$. superba. The content of acid-soluble inorganic $\mathrm{Al}$ in soil of mixed plantation of $C$. lanceolata also indicated a decreasing tendency, whereas the content of humic acid $\mathrm{Al}$ indicated an increasing tendency. Meanwhile, soil $\mathrm{pH}$ indicated an increasing tendency and had a negative correlation with all chemical forms of $\mathrm{Al}$ in soil. These results indicated that mixed planting patterns of $C$. lanceolata could reduce active $\mathrm{Al}$ in soil and would be an alternative alleviation method to control the harmful effects of $\mathrm{Al}$ on $C$. lanceolata forest.
\end{abstract}

Keywords: Cunninghamia lanceolata, exchangeable Al, monomer hydroxy $\mathrm{Al}$, acid-soluble inorganic $\mathrm{Al}$, humic acid Al

\section{Introduction}

Aluminum (Al) in soil is one of the toxic metals to plants, especially for plants growth in acid soil (Kochian et al., 2015). Al can be absorbed by plants, although it is not a nutrient element (Arunakumara et al., 2013). Al in plant cells would be combined with cell pectin, membrane components, proteins, and nucleic acids (Matsumoto, 1988; Jones and Kochian, 1997; Tabuchi et al., 2001; Arunakumara et al., 2013; Shahnawaz et al., 2016), and thus it can influence the growth, cell membrane integrity, photosynthesis, nitrogen metabolism, nutrient uptake, and deoxyribonucleic acid (DNA) fragmentation (Prabagar et al., 2011; Ribeiro et al., 2013; Cruz et al., 2014; Yang et al., 2015; Anjum et al., 2016; Vardar et al., 2016; Awasthi et al., 2017). The potential toxicity of active Al in the terrestrial ecosystem was a major factor leading to the forest degradation overspreading across Central Europe in the 1970s (Ulrich et al., 1980).

However, phytotoxicity of soil Al does not depend on the total content of $\mathrm{Al}$ in soil but on its chemical forms (Shahnawaz et al., 2016). In fact, Al is the most abundant metal present in the Earth's crust (Arunakumara et al., 2013). It exists in many different forms in soil such as $\mathrm{Al}^{3+}, \mathrm{Al}(\mathrm{OH})^{2+}, \mathrm{Al}(\mathrm{OH})_{2}{ }^{+}, \mathrm{Al}(\mathrm{OH})_{3}, \mathrm{Al}-\mathrm{OH}$ polymer, Al-F complex, Al$\mathrm{SO}_{4}$ complex, phosphate, organic species, carbonate species, and oxide species (Wang et al., 2007; Zhou et al., 2011; Shahnawaz et al., 2016). Al toxicity to plants varies according to different chemical forms. Al in insoluble form is nonphytotoxic whereas $\mathrm{Al}^{3+}, \mathrm{Al}(\mathrm{OH})^{2+}$, and $\mathrm{Al}(\mathrm{OH})_{2}{ }^{+}$are considered as the most toxic forms in soil and named 
active Al (Zhou et al., 2011; Shahnawaz et al., 2016). The distribution of Al forms in the soil can be influenced by many factors including soil $\mathrm{pH}$, soil types, predominant clay mineral, organic matter, organic acid, and plant species (Xu and Zhang, 2017). Therefore, many alleviating methods for Al toxicity are associated with the above-mentioned factors. Controlling soil acidity is one of the most common methods to alleviate Al toxicity, because $\mathrm{Al}$ forms are found to be dependent on soil $\mathrm{pH}$. Under acidic conditions, $\mathrm{Al}$ can be solubilized into more toxic forms. The addition of alkali materials such as calcium carbonate, magnesium limestone, and calcium silicate could increase soil $\mathrm{pH}$ and reduce the stress effects of $\mathrm{Al}$ on plants (Cristancho et al., 2011; Elisa et al., 2016). Addition of organic materials and mineral ions are also alternative options (Muhrizal et al., 2003; Yang et al., 2009; Iqbal, 2014; Liu et al., 2014). For forest plants, a mixed species plantation might be an effective ecological method to alleviate Al toxicity. However, only a few cases have been reported until now (Li et al., 2008; Lei et al., 2014).

Chinese fir (Cunninghamia lanceolata) is one of the most important timber tree species in Southern China where the soil is acidic and ferrallitic. Increasing soil acidification caused by acid rain and the continuous planting of $C$. lanceolata will inevitably lead to Al toxicity in C. lanceolata (Liu et al., 2014), which may be closely related to its chemical forms in soil. A mixed plantation of $C$. lanceolata with other forest species has been confirmed to have promoting effects on phosphorus nutrition, microbial community, chemical properties, and carbon storages in soil (Zou et al., 1995; Liu et al., 2010; Richards et al., 2010; Wang et al., 2010). However, little is known about the changes in $\mathrm{Al}$ chemical forms. The aim of this study is to examine the effects of different mixed planting patterns of $C$. lanceolata on the chemical forms of $\mathrm{Al}$ in soils including exchangeable $\mathrm{Al}$, monomer hydroxy $\mathrm{Al}$, acid-soluble inorganic $\mathrm{Al}$, and humic acid $\mathrm{Al}$ in both the rhizosphere and bulk soils. One-year-old seedlings of $C$. lanceolata were used, and the mixed plantation of $C$. lanceolata with both Michelia macclurei and Schima superba in high planting density was carried out.

\section{Materials and methods}

\section{Study area}

The experiment was performed in the Experimental Station of Forest located at a hillside of the campus of Fujian Agriculture and Forestry University, in Fujian Province, China $\left(119^{\circ} 14^{\prime} \mathrm{N}\right.$ and $\left.26^{\circ} 05^{\prime} \mathrm{E}\right)$ where has subtropical monsoon climate with an annual average temperature of $15-20^{\circ} \mathrm{C}$ and an average annual rainfall of 900-2100 mm. The experiment started on May 8, 2014 when it was spring.

Soil for this study was a kind of acid red soil (based on Chinese Soil Taxonomy). The clay mineral composition was characterized by kaolinite with gibbsite and ferric oxide. The soil was taken from the same site of the Experimental Station of Forest. There were no trees except some natural herbs in this chosen area. Only the soil down to a depth of 1-2 m was collected in order to avoid any previous plant residues. Soil properties were examined before the onset of our experiment. The results are presented in Table 1.

Table 1. Properties of the soil used in this experiment

\begin{tabular}{c|c|c|c|c|c|c|c}
\hline $\mathbf{p H}$ & $\begin{array}{c}\text { Total N } \\
(\boldsymbol{\%})\end{array}$ & $\begin{array}{c}\text { Total P } \\
(\boldsymbol{\%})\end{array}$ & $\begin{array}{c}\text { Total K } \\
(\boldsymbol{\%})\end{array}$ & $\begin{array}{c}\text { Available N } \\
\left(\mathbf{m g} / \mathbf{k g}^{-\mathbf{1}}\right)\end{array}$ & $\begin{array}{c}\text { Available P } \\
\left(\mathbf{m g} / \mathbf{k g}^{-1}\right)\end{array}$ & $\begin{array}{c}\mathbf{A v a i l a b l e ~ K} \\
\left(\mathbf{m g} / \mathbf{k g}^{-1}\right)\end{array}$ & $\begin{array}{c}\text { Organic } \\
\mathbf{m a t t e r}(\boldsymbol{\%})\end{array}$ \\
\hline 4.29 & 0.048 & 0.017 & 1.48 & 58.9 & 1.45 & 42.3 & 0.7 \\
\hline
\end{tabular}




\section{Mixed plantation}

One-year-old seedlings of C. lanceolata, M. Macclurei, and S. superba were used as plant materials. Seedlings were planted in pots (length $\times$ width $\times$ height $=1 \mathrm{~m} \times 1 \mathrm{~m} \times$ $0.8 \mathrm{~m}$ ) (Fig. 1). The pots were made of concrete and filled with soils mentioned in the above "Soil" section. Five different planting patterns including pure $C$. lanceolata, pure M. macclurei, pure $S$. superba, C. lanceolata in mixture with $M$. macclurei (1:1) and C. lanceolata in mixture with $S$. superba (1:1) were compared. For each planting patterns, there were four replicates (one pot per replicate). For each replicate, there were 16 seedlings for pure planting patterns and 8:8 seedlings for mixed planting patterns, respectively (Table 2). Seedling to seedling distance was $20 \mathrm{~cm}$. All seedlings was watered regularly using tap water to avoid the pot soil too dry. The watering requency differed in different seasons (once per day in spring and autumn, once two days in winter, twice per day in summer). Four seedlings ( $2: 2$ for mixed planting patterns) were uprooted together with surrounding soil to the depth of $50 \mathrm{~cm}$ by using a plastic tube $(15 \mathrm{~cm}$ in diameter for 6 months seedlings or $20 \mathrm{~cm}$ in diameter for 18 months seedlings) with sharp edge after 6 and 18 months, respectively. The uprooted soils were separated into rhizosphere and bulk soil. The rhizosphere soil was collected by gently shaking the plant roots and carefully removing the soil adhering to them. The rest soil was considered as bulk soil. Both rhizosphere and bulk soils were air-dried, passed through 2-mm sieve after removing visible plant material for further analyses.

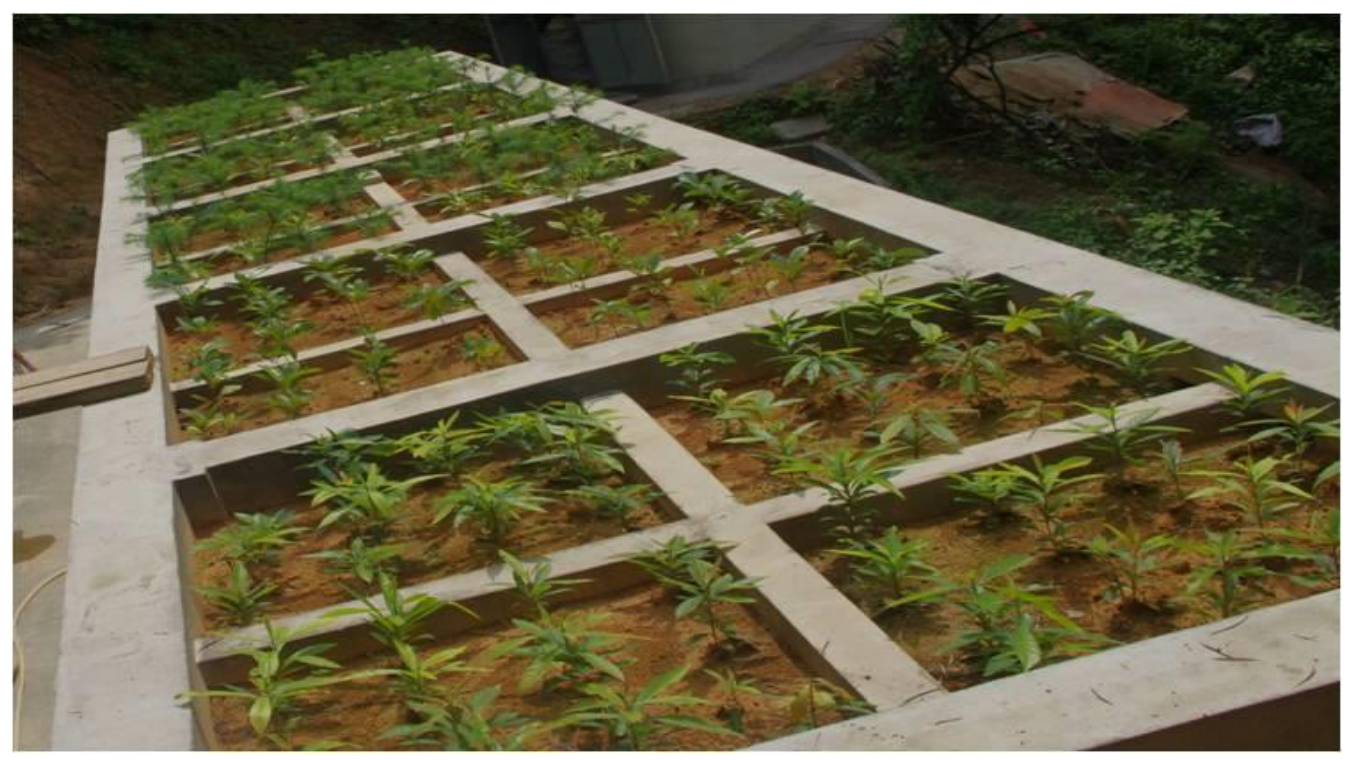

Figure 1. Soil culture experiment

Table 2. Design of experiment

\begin{tabular}{c|c|c|c|c}
\hline \multirow{2}{*}{ No } & \multirow{2}{*}{ Planting patterns } & \multicolumn{3}{|c}{ Plants/pot } \\
\cline { 3 - 5 } & & C. lanceolata & M. macclurei & S. superba \\
\hline 1 & Pure C. lanceolata & 16 & 16 & \\
2 & Pure M. macclurei & & & 16 \\
3 & Pure S. superba & 8 & 8 & 8 \\
4 & C. lanceolata/M. macclurei & 8 & & \\
5 & C. lanceolata/S. superba & & & \\
\hline
\end{tabular}




\section{Determination of Al chemical forms and $\mathrm{pH}$ in soil}

Chemical forms of $\mathrm{Al}$ in soils were extracted using continuous extraction methods (Huang and Qu, 1996; Zhou et al., 2011). Al in each fraction was determined by an auto discrete analyzer (SmartChem 200, WestCo Scientific Instruments Inc., and Italy).

Exchangeable $\mathrm{Al}: 1 \mathrm{~mol} \mathrm{~L}^{-1} \mathrm{KCl}$ was used to extract exchangeable $\mathrm{Al}$ (mainly $\mathrm{Al}^{3+}$ ).

Monomer hydroxy $\mathrm{Al}$ : $1 \mathrm{~mol} \mathrm{~L}^{-1} \mathrm{CH}_{3} \mathrm{COONH}_{4}$ was used to extract monomer hydroxy $\mathrm{Al}$ (mainly $\mathrm{Al}(\mathrm{OH})^{2+}$ and $\mathrm{Al}(\mathrm{OH})_{2}{ }^{+}$).

Acid-soluble inorganic $\mathrm{Al}: 1 \mathrm{~mol} \mathrm{~L}^{-1} \mathrm{HCl}$ was used to extract acid-soluble inorganic $\mathrm{Al}$ (mainly $\left.\mathrm{Al}(\mathrm{OH})_{3}\right)$.

Humic acid $\mathrm{Al}: 0.5 \mathrm{~mol} \mathrm{~L}^{-1} \mathrm{NaOH}$ was used to extract humic acid $\mathrm{Al}$ (mainly humic acid bound $\mathrm{Al}$ ).

Soil $\mathrm{pH}$ was measured in $1 \mathrm{~mol} \mathrm{~L}^{-1} \mathrm{KCl}(1: 2.5$, w:v) using an PHS-3C $\mathrm{pH}$ meter (Shanghai INESA Scientific Instrument Co., Ltd, China).

\section{Statistical analysis}

Initial data were analyzed using Microsoft Excel. Values were represented as the means of four replicates (Mean \pm SD) for each treatment. The relationship between soil $\mathrm{pH}$ and chemical forms of $\mathrm{Al}$ in soil was also analyzed using linear regression in Microsoft Excel. Differences between different treatments were statistically calculated using method of Tukey for analysis of variance (ANOVA) in SPSS 13.0. The data were considered to be significantly different at $P<0.05$.

\section{Results}

\section{Content of exchangeable Al}

As presented in Fig. 2, the content of exchangeable $\mathrm{Al}$ deceased by $2.3-3.0 \%$ in rhizosphere soil and $7.3-8.1 \%(P<0.01$ for 6 months and $P<0.05$ for 18 months $)$ in bulk soil of mixed plantation of $C$. lanceolata with $M$. macclure $i$ when compared to that of pure $C$. lanceolata plantation. The content of exchangeable $\mathrm{Al}$ increased by $2.1-5.4 \%$ in rhizosphere soil whereas it decreased by $6.6-6.9 \%(P<0.01$ for 6 months $)$ in bulk soil of mixed plantation of $C$. lanceolata with $S$. superba.

As showed in Table 3, the content of exchangeable Al increased in rhizosphere soil but decreased in bulk soils of $M$. macclurei after mixed plantation. The soil exchangeable $\mathrm{Al}$ reduced in both rhizosphere and buck soils of $S$. superba, and the changes were significant for the 6-month treatment.

Table 3. Changes in content of exchangeable Al in soils of M. macclurei and S. superba after mixed plantation with $C$. lanceolata (Mean $+S D, n=4$ for all the treatments)

\begin{tabular}{c|c|c|c|c}
\hline \multirow{2}{*}{ Planting patterns } & \multicolumn{2}{|c|}{ Rhizosphere soil $\mathbf{( m g / k g})$} & \multicolumn{2}{c}{ Bulk soil (mg/kg) } \\
\cline { 2 - 5 } & $\mathbf{6 ~ m o n t h s}$ & $\mathbf{1 8}$ months & $\mathbf{6}$ months & $\mathbf{1 8}$ months \\
\hline M. macclurei & $190.9 \pm 22.3 \mathrm{a}$ & $194.4 \pm 9.2 \mathrm{~b}$ & $224.3 \pm 14.6 \mathrm{a}$ & $221.9 \pm 12.1 \mathrm{a}$ \\
C. lanceolata/M. macclurei & $209.5 \pm 19.5 \mathrm{a}$ & $215.9 \pm 10.7 \mathrm{a}$ & $220.4 \pm 3.6 \mathrm{a}$ & $219.9 \pm 8.5 \mathrm{a}$ \\
S. superba & $189.5 \pm 5.1 \mathrm{a}$ & $197.1 \pm 7.8 \mathrm{a}$ & $238.1 \pm 3.0 \mathrm{a}$ & $226.7 \pm 9.1 \mathrm{a}$ \\
C. lanceolata/S. superba & $179.7 \pm 4.4 \mathrm{a}$ & $191.1 \pm 6.6 \mathrm{a}$ & $224.1 \pm 3.4 \mathrm{~b}$ & $217.8 \pm 4.37 \mathrm{a}$ \\
\hline
\end{tabular}

Different letters indicate significant differences at $P<0.05$ between pure plantation and its mixed plantation as determined by the method of Tukey test 

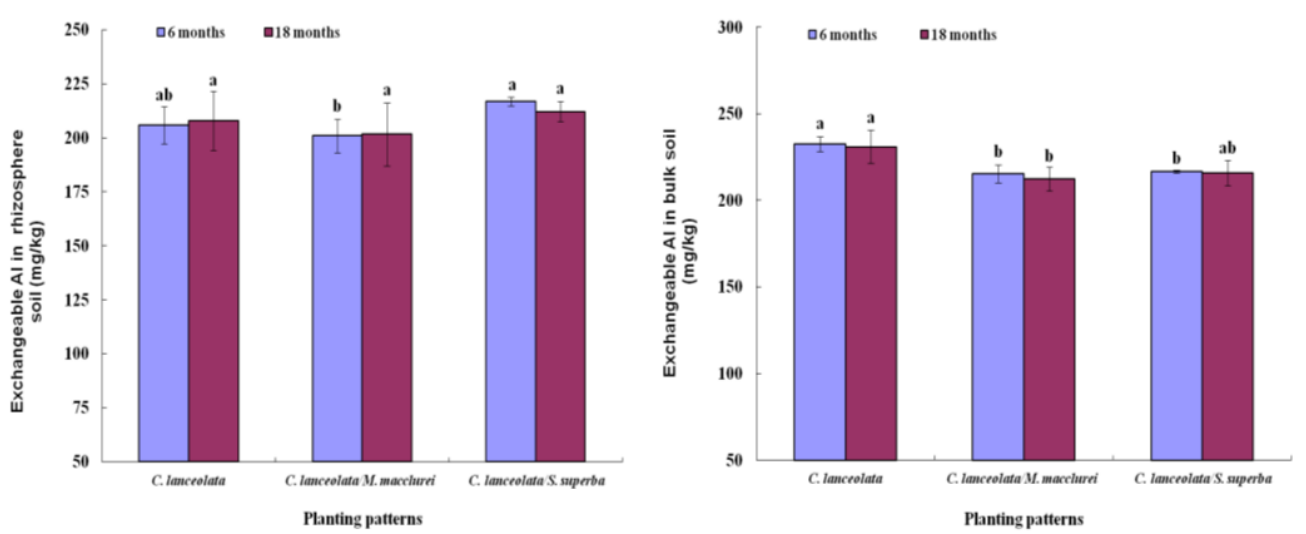

Figure 2. Effect of the mixed plantation of C. lanceolata on the content of exchangeable Al in both rhizosphere and bulk soils. Error bars are standard errors of the mean $(n=4$ for all the treatments). Significant differences $(P<0.05)$ between pure $C$. lanceolata and its mixed plantation are marked by different letters

\section{Content of monomer hydroxy Al}

Content of monomer hydroxy Al (Fig. 3) in rhizosphere soil of mixed plantation of C. lanceolata with $M$. macclurei was $13.1-14.2 \%$ (p $<0.01$ for 18 months) less than that of pure $C$. lanceolata plantation whereas the value in bulk soil was $2.6-12.4 \%$ ( $P<0.01$ for 18 months). The content of monomer hydroxy $\mathrm{Al}$ in bulk soil of mixed plantation of $C$. lanceolata with $S$. superba was $7.2-7.3 \%$ ( $P<0.05$ for 18 months) less than that of pure $C$. lanceolata plantation whereas its changing trend in the rhizosphere soil was inconsistent between 6 and 18 months treatments.
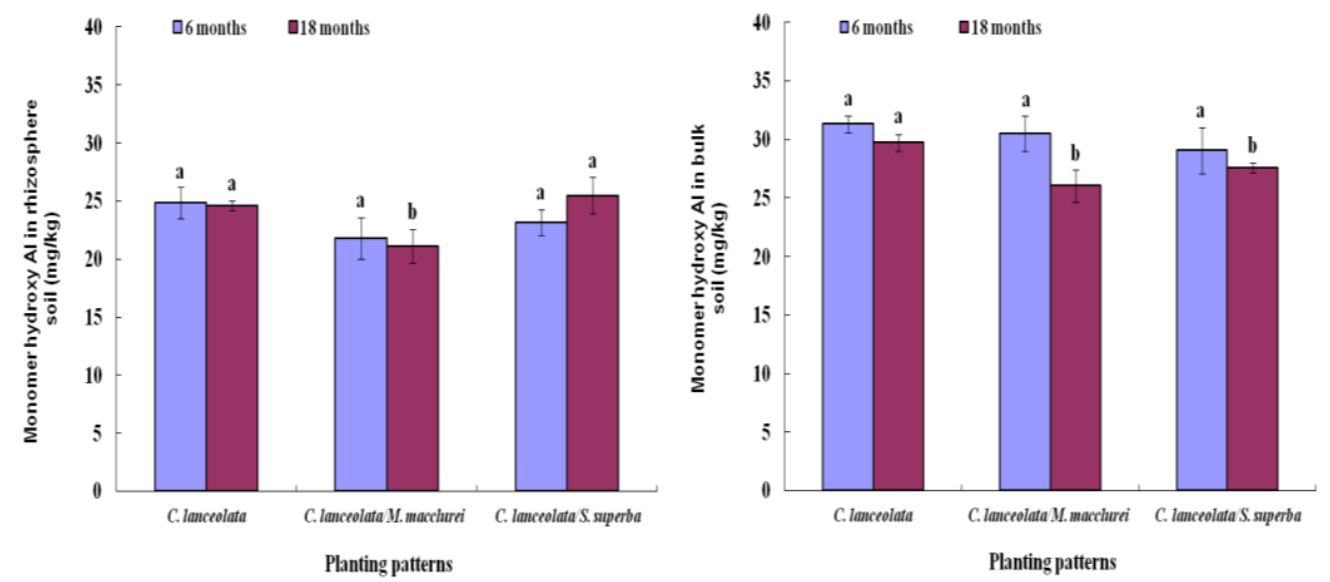

Figure 3. Effect of the mixed plantation on the content of monomer hydroxy Al in both rhizosphere and bulk soils. Error bars are standard errors of the mean $(n=4$ for all the treatments). Significant differences between pure C. lanceolata and its mixed plantation are marked by different letters

The data of the effects of mixed plantation on M. macclurei and S. superba soils showed that the content of monomer hydroxy Al in both rhizosphere and bulk soils (Table 4) of M. macclure i in mixture with C. lanceolata and S. superba in mixture with 
C. lanceolata was less than that of their pure plantations. The difference in monomer hydroxy $\mathrm{Al}$ content in bulk soil between mixed plantation and pure plantation was sinificant after a 6-month mixed plantation treatment of both species, and a 18-month mixed plantation treatment of $S$. superba.

Table 4. Changes in content of monomer hydroxy Al in soils of M. macclurei and S. superba after mixed plantation with C. lanceolata (Mean $+S D, n=4$ for all the treatments)

\begin{tabular}{c|c|c|c|c}
\hline \multirow{2}{*}{ Planting patterns } & \multicolumn{2}{|c|}{ Rhizosphere soil $\mathbf{( m g} / \mathbf{k g})$} & \multicolumn{2}{c}{ Bulk soil $\mathbf{( m g} / \mathbf{k g})$} \\
\cline { 2 - 5 } & $\mathbf{6}$ months & $\mathbf{1 8}$ months & $\mathbf{6}$ months & $\mathbf{1 8}$ months \\
\hline M. macclurei & $22.6 \pm 4.5 \mathrm{a}$ & $30.5 \pm 2.7 \mathrm{a}$ & $36.2 \pm 5.3 \mathrm{a}$ & $32.7 \pm 3.5 \mathrm{a}$ \\
C. lanceolata/M. macclurei & $21.3 \pm 1.6 \mathrm{a}$ & $29.5 \pm 0.4 \mathrm{a}$ & $28.7 \pm 2.3 \mathrm{~b}$ & $30.1 \pm 1.6 \mathrm{~b}$ \\
S. superba & $28.2 \pm 4.4 \mathrm{a}$ & $31.2 \pm 2.2 \mathrm{a}$ & $30.6 \pm 0.7 \mathrm{a}$ & $29.8 \pm 0.2 \mathrm{a}$ \\
C. lanceolata/S. superba & $23.8 \pm 3.1 \mathrm{a}$ & $30.2 \pm 1.6 \mathrm{a}$ & $26.4 \pm 1.7 \mathrm{~b}$ & $28.5 \pm 2.0 \mathrm{a}$ \\
\hline
\end{tabular}

Different letters indicate significant differences at $P<0.05$ between pure plantation and its mixed plantation as determined by the method of Tukey test

\section{Content of acid-soluble inorganic Al}

Content of acid-soluble inorganic Al (Fig. 4) in rhizosphere soil of mixed plantation of $C$. lanceolata with $M$. macclure $i$ was $6.5-9.9 \%$ less than that of pure $C$. lanceolata plantation whereas it increased slightly in the bulk soil. The content of acid-soluble inorganic $\mathrm{Al}$ in rhizosphere soil of mixed plantation of $C$. lanceolata with $S$. superba was $6.2-9.6 \%$ less than that of pure $C$. lanceolata plantation whereas the value in bulk soil was $2.5-7.0 \%$. The statistic analysis did not show that all of the above changes in the content of acid-soluble inorganic $\mathrm{Al}$ after mixed plantation were significant.
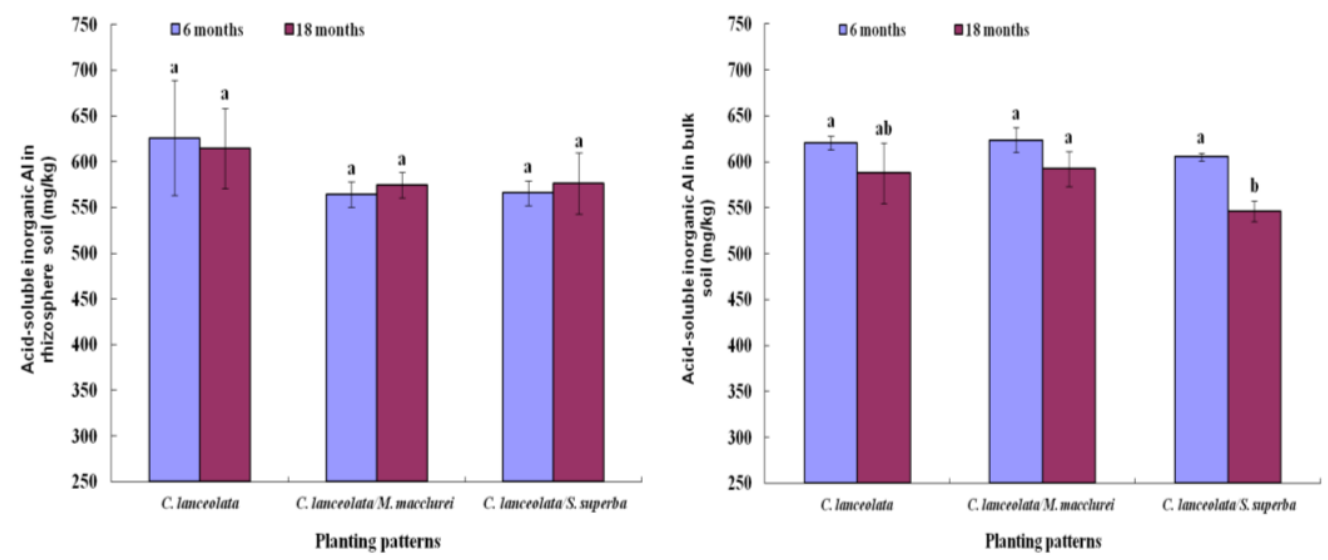

Figure 4. Effect of the mixed plantation on the content of acid-soluble inorganic Al in both rhizosphere and bulk soils. Error bars were standard errors of the mean $(n=4$ for all the treatments). Significant differences between pure C. lanceolata and its mixed plantation are marked by different letters

Content of acid-soluble inorganic Al in rhizosphere soil of both M. macclurei and S. superba increased after mixed plantation (Table 5). But the changes were not significant. In contrast, the content of acid-soluble inorganic Al in bulk soil was significantly reduced after a 6-month treatment. 
Table 5. Changes in content of acid-soluble inorganic Al in soils of M. macclurei and S. superba after mixed plantation with C. lanceolata (Mean $+S D, n=4$ for all the treatments)

\begin{tabular}{c|c|c|c|c}
\hline \multirow{2}{*}{ Planting patterns } & \multicolumn{2}{|c|}{ Rhizosphere soil (mg/kg) } & \multicolumn{2}{c}{ Bulk soil (mg/kg) } \\
\cline { 2 - 5 } & 6 months & $\mathbf{1 8 ~ m o n t h s}$ & $\mathbf{6}$ months & $\mathbf{1 8 ~ m o n t h s}$ \\
\hline M. macclurei & $598.6 \pm 30.7 \mathrm{a}$ & $613.6 \pm 36.1 \mathrm{a}$ & $619.7 \pm 18.9 \mathrm{a}$ & $591.6 \pm 57.2 \mathrm{a}$ \\
C. lanceolata/M. macclurei & $607.1 \pm 10.6 \mathrm{a}$ & $628.2 \pm 10.3 \mathrm{a}$ & $588.6 \pm 9.3 \mathrm{~b}$ & $583.2 \pm 13.8 \mathrm{a}$ \\
S. superba & $635.2 \pm 15.5 \mathrm{a}$ & $645.0 \pm 32.2 \mathrm{a}$ & $624.4 \pm 11.7 \mathrm{a}$ & $596.9 \pm 17.1 \mathrm{a}$ \\
C. lanceolata/S. superba & $656.8 \pm 12.2 \mathrm{a}$ & $667.9 \pm 7.3 \mathrm{a}$ & $592.9 \pm 13.7 \mathrm{~b}$ & $631.9 \pm 29.6 \mathrm{a}$ \\
\hline
\end{tabular}

Different letters indicate significant differences at $P<0.05$ between pure plantation and its mixed plantation as determined by the method of Tukey test

\section{Content of humic acid Al}

Content of humic acid Al (Fig. 5) in rhizosphere and bulk soils of mixed plantation of $C$. lanceolata with $S$. superba increased by 5.4-9.9\% and 5.4-6.2\% ( $P<0.01$ for bulk soil after 6 months) when compared to that of pure $C$. lanceolata plantation. For mixed plantation of $C$. lanceolata with $M$. macclurei, the content of humic acid $\mathrm{Al}$ had an increase of $0.8-3.4 \%$ in rhizosphere soil and a decrease of $0.7-3.5 \%$ in bulk soil, but the above changes were not significant.

For both $M$. macclurei and S. superba, the content of humic acid Al increased after mixed plantation (Table 6 ). The changes were significante in rhizosphere soil except 18 month treatment of $M$. macclurei.


Figure 5. Effect of the mixed plantation on the content of humic acid Al in both rhizosphere and bulk soils. Error bars are standard errors of the mean ( $n=4$ for all the treatments). Significant differences between pure C. lanceolata and its mixed plantation are marked by different letters

Table 6. Changes in content of humic acid Al in soils of M. macclurei and S. superba after mixed plantation with $C$. lanceolata (Mean $+S D, n=4$ for all the treatments)

\begin{tabular}{c|c|c|c|c}
\hline \multirow{2}{*}{ Planting patterns } & \multicolumn{2}{|c|}{ Rhizosphere soil $\mathbf{( m g / k g})$} & \multicolumn{2}{c}{ Bulk soil $\mathbf{m g} / \mathbf{k g})$} \\
\cline { 2 - 5 } & $\mathbf{6 ~ m o n t h s}$ & $\mathbf{1 8}$ months & $\mathbf{6}$ months & $\mathbf{1 8}$ months \\
\hline M. macclurei & $1856.1 \pm 223.1 \mathrm{~b}$ & $1874.4 \pm 232.7 \mathrm{a}$ & $2084.4 \pm 280.6 \mathrm{a}$ & $2060.5 \pm 271.2 \mathrm{a}$ \\
C. lanceolata/M. macclurei & $2051.3 \pm 101.7 \mathrm{a}$ & $1983.4 \pm 81.5 \mathrm{a}$ & $2145.6 \pm 52.5 \mathrm{a}$ & $2073.0 \pm 117.9 \mathrm{a}$ \\
S. superba & $1907.0 \pm 20.7 \mathrm{~b}$ & $1925.9 \pm 38.8 \mathrm{~b}$ & $2055.0 \pm 42.8 \mathrm{~b}$ & $2076.9 \pm 93.2 \mathrm{a}$ \\
C. lanceolata/S. superba & $2197.1 \pm 145.9 \mathrm{a}$ & $2160.4 \pm 95.8 \mathrm{a}$ & $2135.9 \pm 17.9 \mathrm{a}$ & $2130.1 \pm 96.1 \mathrm{a}$ \\
\hline
\end{tabular}

Different letters indicate significant differences at $P<0.05$ between pure plantation and its mixed plantation as determined by the method of Tukey test 


\section{Soil pH}

The changed in soil $\mathrm{pH}$ was also observed after mixed plantation (Fig. 6). There was an increase in $\mathrm{pH}$ in both rhizosphere $(P<0.05)$ and bulk soils $(P<0.05$ after 6 months) of the mixed plantation of $C$. lanceolata with $M$. macclure $i$ when compared to that of pure $C$. lanceolata plantation. For mixed plantation of $C$. lanceolata with S. superba, only bulk soil $\mathrm{pH}$ showed a significant increase $(P<0.05)$. Table 7 shows the relationship between soil $\mathrm{pH}$ and four chemical forms of $\mathrm{Al}$ in soil of $C$. lanceolata. We found that soil $\mathrm{pH}$ had a negative correlation with exchangeable $\mathrm{Al}$ and monomer hydroxy $\mathrm{Al}$, but the correlation was not significant. There was also a negative correlation between soil $\mathrm{pH}$ and both exchangeable Al and humic acid Al in soils of $M$. macclurei and $S$. superba plantation which were used as mixed species with C. lanceolata (Table 8). The the correlation between soil $\mathrm{pH}$ and exchangeable $\mathrm{Al}$ in soil was significant at 0.01 level.
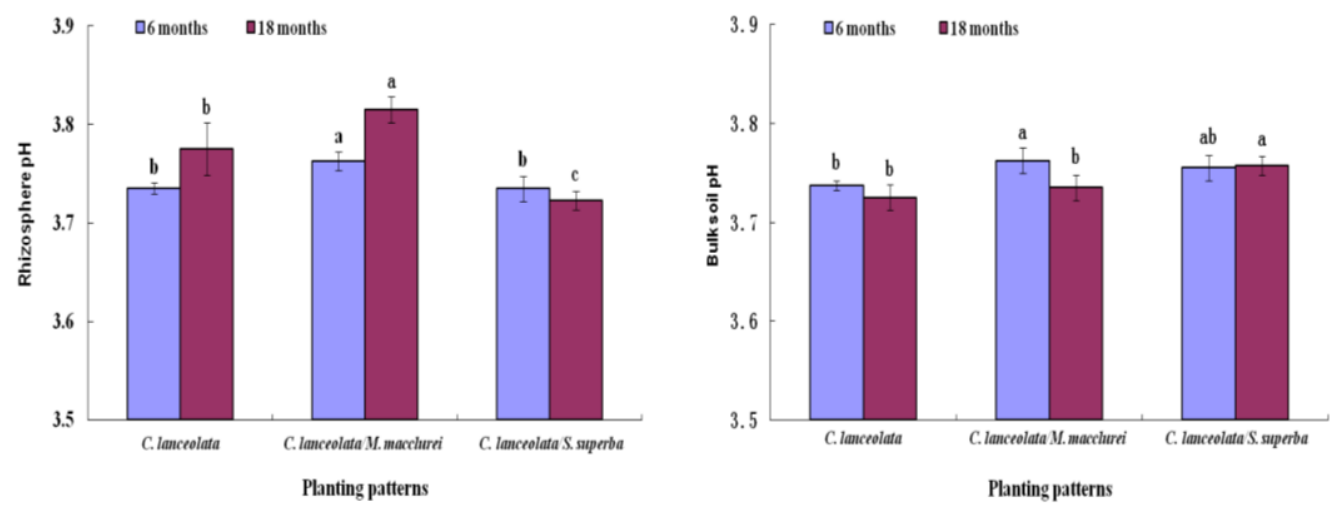

Figure 6. Effect of different mixed planting patterns of C. lanceolata on soil $p H$. (a) Rhizosphere soil; (b) Bulk soil. Error bars were standard errors of the mean $(n=4$ for all the treatments). Significant differences between pure C. lanceolata and its mixed plantation are marked by different letters

Table 7. Relationship between soil $\mathrm{pH}$ and chemical forms of $\mathrm{Al}$ in soil of $\mathrm{C}$. lanceolata $(n=12)$

\begin{tabular}{l|c|c}
\hline & Chemical forms & Correlation coefficient \\
\hline \multirow{3}{*}{ Soil pH } & Exchangeable Al & -0.5562 \\
& monomer hydroxy Al & -0.4238 \\
& Acid-soluble inorganic Al & -0.0960 \\
& Humic acid Al & -0.1589 \\
\hline
\end{tabular}

Table 8. Relationship between soil $\mathrm{pH}$ and chemical forms of $\mathrm{Al}$ in soil of $M$. macclurei and S. superba $(n=16)$

\begin{tabular}{c|c|c}
\hline & Chemical forms & Correlation coefficient \\
\hline \multirow{3}{*}{ Soil $\mathrm{pH}$} & Exchangeable Al & $-0.6955^{* *}$ \\
& monomer hydroxy Al & 0.0173 \\
& Acid-soluble inorganic Al & $0.5411^{*}$ \\
& Humic acid Al & -0.4577 \\
\hline
\end{tabular}

$* \mathrm{P}<0.05, * * \mathrm{P}<0.01$ 


\section{Discussion}

Our results indicated that there were differences in chemical forms of soil $\mathrm{Al}$ between mixed and pure plantations of $C$. lanceolata. The mixed plantation of $C$. lanceolata with both $M$. macclurei and $S$. superba could reduce the exchangeable Al and monomer hydroxy $\mathrm{Al}$ content in all soils except in the rhizosphere soil of mixed plantation of $C$. lanceolata with S. superba (Figs. 2 and 3). This decreasing tendency was consistent with the result of $\mathrm{Li}$ et al. (2010) on the mixed plantation of Pinus massoniana with Cinnamomum camphora. Our finding could be explained through some research results related to mixed plantation in the literatures. It has been documented that mixed plantation could increase plant biomass, soil $\mathrm{pH}$, organic carbon, organic matter, phosphorus nutrition, soil $\mathrm{N}$ availability, and microbial biomass, as well as an improvement in microbial community diversities and enzyme activities ( $\mathrm{Li}$ et al., 2010; Richards et al., 2010; Singh et al., 2012; Forrester et al., 2013; Dutta and Hossain, 2017; Tchichelle et al., 2017). Then such changes may be attributed to the changes in $\mathrm{Al}$ chemical forms because the distribution of $\mathrm{Al}$ chemical forms in soil could be affected by some of the above-mentioned factors such as soil $\mathrm{pH}$, organic carbon, organic matter and phosphorus nutrition (Godsey et al., 2007; Fang et al., 2014; Hagvall et al., 2015). In our experiement, $C$. lanceolata is an important coniferous species whereas $M$. macclurei and $S$. superba are broadleaved tree species. Broadleaf litter generally has higher nutrient concentrations and lower lignin and polyphenol concentrations than needle litter and has faster litter decomposition rate (Prescott et al., 2004). Moreover, coniferous species may create more acid soils (Götmark et al., 2005). Therefore, introducing broadleaved species in C. lanceolata plantation would be very useful for the improvement of soil properties. Our results showed that the soil $\mathrm{pH}$ in C. lanceolata had an increasing tendency after mixed plantation. This results is in accordance with Cremer et al. (2017), who reported that a mixed plantation of Douglas fir (Pseudotsuga menziesii) and European beech (Fagus sylvatica) had a higher forest floor and mineral soil $\mathrm{pH}$ than pure conifer stands. Similar report came from Berger et al. (2004), who documented that soil pHs under mixed species were higher than soil $\mathrm{pHs}$ under pure spruce. Statistic analysis further showed that there was a negative correlation between soil $\mathrm{pH}$ in $C$. lanceolata and $\mathrm{Al}$ chemicla forms in soil, indicating that the change in soil $\mathrm{pH}$ may be one of the reasons for the changes in $\mathrm{Al}$ chemical forms after mixed plantation. However, further studies on the effects of the mixed plantation of $C$. lanceolata with both species on other soil properties and their relationships with $\mathrm{Al}$ chemical forms are needed in the future.

Our results also showed that the content of acid-soluble inorganic Al in soils of C. lanceolata decreased after mixed plantation except that in the rhizosphere soil of mixed $C$. lanceolata and M. macclurei plantation (Fig. 4), whereas content of humic acid Al increased in all soils except in the rhizosphere soil of mixed $C$. lanceolata and M. macclurei plantation (Fig. 5). Yang had found that there was a significant increase in humic acid in a the mixed forest of $C$. lanceolata when compared to its pure stand (Yang et al., 2002). Therefore, the increase of humic acid Al in soil in our experiment may be because of the increase of humic acid after mixed plantation of $C$. lanceolata. As mentioned in the introduction section, different $\mathrm{Al}$ forms in soil differed in their phytotoxicity (Zhou et al., 2011; Shahnawaz et al., 2016). The toxicity potential was ranked in decreasing order as exchangeable $\mathrm{Al}$, monomer hydroxy $\mathrm{Al}$, acid-soluble inorganic $\mathrm{Al}$, and humic acid $\mathrm{Al}$. Therefore, the decrease in exchangeable $\mathrm{Al}$, monomer hydroxy $\mathrm{Al}$, and acid-soluble inorganic $\mathrm{Al}$ contents and the increase in humic acid $\mathrm{Al}$ 
content indicated that such a mixed plantation could decrease the toxic $\mathrm{Al}$ forms, and consequently, Al phytotoxicity would be reduced.

We observed that chemical forms of $\mathrm{Al}$ in soil of $M$. macclurei and $S$. superba plantation also changed to different extent after mixed plantation with $C$. lanceolata. The exchangeable $\mathrm{Al}$ and monomer hydroxy $\mathrm{Al}$ content showed a decreasing trend as that of $C$. lanceolata. These results suggested that the mixed plantation is not only useful for $C$. lanceolata, but is also good for the two mixed species as for soil aluminum toxicity.

\section{Conclusions}

The experimental results indicated that mixed plantation of $C$. lanceolata could change the distribution of $\mathrm{Al}$ speciation in the soil. However, the changes varied among different chemical forms. There was a decreasing tendency in exchangeable $\mathrm{Al}$ in both mixed planting patterns. Similar results were also observed in the content of monomer hydroxy $\mathrm{Al}$ and acid-soluble inorganic Al. These results indicated that there was a general decrease tendency in the content of chemical forms with higher phytotoxicity including two most active chemical forms of $\mathrm{Al}$ in soils (i.e., exchangeable $\mathrm{Al}$ and monomer hydroxy Al). Therefore, we suggested that mixed planting patterns could be an alternative alleviation method to control the harmful Al effects on C. lanceolata forest although further studies are still needed.

Acknowledgements. We thank Rongmei Zhang for her great assistance in the entire soil culture and sampling. We are also grateful to Yu Chen for his professional advice in this study, Guangqiu Cao for his help with getting the plant material, Bifei Hang for her help with the analysis of Al content. We would also like to thank the National Natural Science Foundation of China (grant number 31370609) for providing the funding for this research.

\section{REFERENCES}

[1] Anjum, S. A., Ashraf, U., Khan, I., Tanveer, M., Saleem, M. F., Wang, L. C. (2016): Aluminum and chromium toxicity in maize: implications for agronomic attributes, net photosynthesis, physio-biochemical oscillations, and metal accumulation in different plant parts. - Water, Air, Soil Pollution 227: 326. doi: 10.1007/s11270-016-3013-x.

[2] Arunakumara, K. K. I. U., Walpola, B. C., Yoon, M. H. (2013): Aluminum toxicity and tolerance mechanism in cereals and legumes - a review. - Journal of the Korean Society for Applied Biological Chemistry 56: 1-9.

[3] Awasthi, J. P., Saha, B., Regon, P., Sahoo, S., Chowra, U., Pradhan, A., Roy, A., Panda, S. K. (2017): Morpho-physiological analysis of tolerance to aluminum toxicity in rice varieties of North East India. - PLoS ONE 12(4): e0176357. doi:10.1371/journal. pone. 0176357 .

[4] Berger, T. W., Köllensperger, G., Wimmer, R. (2004): Plant-soil feedback in spruce (Picea abies) and mixed spruce-beech (Fagus sylvatica) stands as indicated by dendrochemistry. - Plant and Soil 264: 69-83.

[5] Cremer, M., Prietzel, J. (2017): Soil acidity an d exchangeable base cation stocks under pure and mixed stands of European beech, Douglas fir and Norway spruce. - Plant and Soil 415(1-2): 393-405. 
[6] Cristancho, J. A. R., Hanafi, M. M., Omar, S. R. S., Rafii, Y. M., Martinez, F. M., Campos, C. E. C. (2011): Alleviation of aluminum in acidic soils and its effect on the growth of hybrid and clonal oil palm seedlings. - Journal of Plant Nutrition 34: 387-401.

[7] Cruz, F. J. R., de Almeida, H. J., dos Santos, D. M. M. (2014): Growth, nutritional status and nitrogen metabolism in Vigna unguiculata (L.) Walp is affected by aluminum. Australian Journal of Crop Science 8: 1132-1139.

[8] Dutta, S., Hossain, M. K. (2017): Effects of mixed plantation on growth and biomass yield of two common plantation trees of Bangladesh. - Journal of Forest Environment Science 33: 22-32.

[9] Elisa, A. A., Ninomiya, S., Shamshuddin, J., Roslan, I. (2016): Alleviating aluminum toxicity in an acid sulfate soil from Peninsular Malaysia by calcium silicate application. Solid Earth 7: 367-374.

[10] Fang, X. M., Chen, F. S., Hu, X. F., Yuan, P. C., Li, J., Chen, X. (2014): Aluminum and nutrient interplay across an age-chronosequence of tea plantations within a hilly red soil farm of subtropical China. - Soil Science and Plant Nutrition 60: 448-459.

[11] Forrester, D. I., Pares, A., O'Hara, C., Khanna, P. K., Bauhus, J. (2013): Soil organic carbon is increased in mixed-species plantations of eucalyptus and nitrogen-fixing acacia. - Ecosystems 16: 123-132.

[12] Godsey, C. B., Pierzynski, G. M., Mengel, D. B., Lamond, R. E. (2007):Changes in soil $\mathrm{pH}$, organic carbon, and extractable aluminum from crop rotation and tillage. - Soil Science Society of America Journal 71: 1038-1044.

[13] Götmark, F., Fridman, J., Kempe, G., Norden, B. (2005): Broadleaved tree species in conifer-dominated forestry: Regeneration and limitation of saplings in southern Sweden. - Forest Ecology and Management 214: 142-157.

[14] Hagvall, K., Persson, P., Karlsson, T. (2015): Speciation of aluminum in soils and stream waters: The importance of organic matter. - Chemical Geology 417: 32-43.

[15] Huang, Y. C., Qu, M. L. (1996): Dissolution of aluminum forms in soil. - Environmental Science 17: 57-59.

[16] Iqbal, M. T. (2014): Phosphorus alleviates aluminum toxicity in aluminum -sensitive wheat seedlings. - Communications in Soil Science and Plant Analysis 45: 437-450.

[17] Jones, D. L., Kochian, L. V. (1997): Aluminum interaction with plasma membrane lipids and enzyme metal binding sites and its potential role in aluminum cytotoxicity. - FEBS Letters 400: 51-57.

[18] Kochian, L. V., Pineros, M. A., Liu, J. P., Magalhaes, J. V. (2015): Plant adaptation to acid soils: the molecular basis for crop aluminum resistance. - Annual Review of Plant Biology 66: 571-598.

[19] Lei, B., Liu, B., Luo, C. D., Zhang, J., Xue, Y. J., Liu, L. (2014): Catabatic effect from artificial mixed plantation of Cunninghamia lanceolata on soil aluminum toxicity. - Acta Ecologica Sinica 34: 2884-2891.

[20] Li, J. L., Tu, P. F., Chen, N., Tang, J. C., Wang, X. R., Nian, H., Liao, H., Yan, X. L. (2008): Effects of tea intercropping with soybean. - Scientia Agricultura Sinica 41: 20402047.

[21] Li, Z. Y., Wang, Y. H., Yu, P. T., Zhang, Z. J., Du, S. C., He, P. W., Xiang, D. J., Li, Z. H. (2010): Soil chemical properties and growth characteristics of mixed plantation of Pinus massoniana and Cinnamomum camphora in the acid rain region of Chongqing China. - Journal of Plant Ecology 34: 387-395.

[22] Liu, L., Duan, Z. H., Xu, M. K., Hu, J. C., Wang, S. L., Hu, Z. G., Zhang, Q. R., Wang, S. J. (2010): Effect of monospecific and mixed Cunninghamia lanceolata plantations on microbial community and two functional genes involved in nitrogen cycling. - Plant and Soil 327: 413-428.

[23] Liu, B., Luo, C. D., Li, X. W., Gray, L., Zhang, F., Liu, M., Ju, J. L., Lei, B. (2014): Research on the threshold of aluminum toxicity and the alleviation effects of exogenous 
calcium, phosphorus, and nitrogen on the growth of Chinese fir seedlings under aluminum stress. - Communications in Soil Science and Plant Analysis 45: 126-139.

[24] Matsumoto, H. (1988): Changes of the structure of pea chromatin by aluminum. - Plant Cell Physiology 29: 281-287.

[25] Muhrizal, S., Shamshuddin, J., Husni, M. H. A., Fauziah, I. (2003): Alleviation of aluminum toxicity in an acid sulfate soil in Malaysia using organic materials. Communications in Soil Science and Plant Analysis 34(19): 2993-3011.

[26] Prabagar, S., Hodson, M., Evans, E. (2011): Silicon amelioration of aluminium toxicity and cell death in suspension cultures of Norway spruce (Picea abies (L.) Karst). Environmental and Experimental Botany 70: 266-276.

[27] Prescott, C. E., Blevins, L. L., Staley, C. (2004): Litter decomposition in British Columbia forests: Controlling factors and influences of forestry activities. - BC Journal of Ecosystems and Management 5: 44-57.

[28] Ribeiro, M. A. Q., Almeida, A. A. F., Mielke, M. S., Gomes, F. P., Pires, M. V., Baligar, V. C. (2013): Aluminum effects on growth, photosynthesis and mineral nutrition of cacao genotypes. - Plant Sciences 36: 1161-1179.

[29] Richards, A. E., Forrester, D. I., Bauhus, J., Scherer-Lorenzen, M. (2010): The influence of mixed tree plantations on the nutrition of individual species: a review. - Tree Physiology 30: 1192-1208.

[30] Shahnawaz, M., Chauhan, R., Sanadhya, D. (2016): Aluminum (Al) toxicity in plants and resistance mechanism: a review. - Journal of Plant Science Research 32: 73-86.

[31] Singh, K., Singh, B., Singh, R. R. (2012): Changes in physico-chemical, microbial and enzymatic activities during the restoration of degraded sodic land: Ecological suitability of mixed forest over monoculture plantation. - Catena 96: 57-67.

[32] Tabuchi, A., Matsumoto, H., Tabuchi, A., Matsumoto, H. (2001): Changes in cell-wall properties of wheat (Triticum aestivum) roots during aluminum induced growth inhibition. - Physiologia Plantarum 112: 353-358.

[33] Tchichelle, S. V., Epron, D., Mialoundama, F., Koutika, L. S., Harmand, J. M., Bouillet, J. P., Mareschal, L. (2017): Differences in nitrogen cycling and soil mineralisation between a eucalypt plantation and a mixed eucalypt and Acacia mangium plantation on a sandy tropical soil. - South Forests 79: 1-8.

[34] Ulrich, B., Mayer, R., Khanna, P. K. (1980): Chemical changes due to acid precipitation in a loess derived soil in central Europe. - Soil Science 130: 193-199.

[35] Vardar, F., Cabuk, E., Ayturk, O., Aydin, Y. (2016): Determination of aluminum induced programmed cell death characterized by DNA fragmentation in Gramineae species. Caryologia 69: 111-115.

[36] Wang, P., Bi, S. P., Zhou, Y. P., Tao, Q. S., Gan, W. X., Xu, Y., Hong, Z., Cai, W. S. (2007): Study of aluminum distribution and speciation in atmospheric particles of different diameters in Nanjing, China. -Atmospheric Environment 41: 5788-5796.

[37] Wang, S. L., Zhang, W. D., Sanchez, F. (2010): Relating net primary productivity to soil organic matter decomposition rates in pure and mixed Chinese fir plantations. - Plant and Soil 334: 501-510.

[38] Xu, X. L., Zhang, J. B. (2017): Research progress on aluminum toxicity and its control in forest soil-plant system. - Chinese Journal of Ecology 36: 1106-1116.

[39] Yang, Y. S., Guo, J. F., Liu, Y. L., Lin R. Y. Chen, G. S. (2002): Composition and properties of soil humus in a mixed forest of Cunninghamia lanceolata and Tsoongiodendron odorum. - Journal of Forestry Research 13(1): 33-36.

[40] Yang, S. Y., Zou, Y. B., Liu, X. H. (2009): Alleviation of soil aluminum phytotoxicity in a typical paddy soil in southern China by using weak organic acids. - Journal of Plant Nutrition 32: 893-906.

[41] Yang, M., Tan, L., Xu, Y. Y., Zhao, Y. H., Cheng, F., Ye, S. M., Jiang, W. X. (2015): Effect of low $\mathrm{pH}$ and aluminum toxicity on the photosynthetic characteristics of different 
fast-growing eucalyptus vegetatively propagated clones. - PLoS ONE 10(6): e0130963. doi: 10.1371/journal.pone.0130963.

[42] Zhou, N., Liu, P., Wang, Z. Y., Xu, G. D. (2011): The effects of rapeseed root exudates on the forms of aluminum in aluminum stressed rhizosphere soil. - Crop Protection 30: 631-636.

[43] Zou, X., Binkley, D., Caldwell, B. A. (1995): Effects of dinitrogen-fixing trees on phosphorus biogeochemical cycling in contrasting forests. - Soil Science Society of America Journal 59: 1452-1458. 